\title{
PENGARUH GREEN STRATEGY, PERCEIVED QUALITY DAN BRAND IMAGE TERHADAP PURCHASE INTENTION PADA PRODUK PLENTY DI JAKARTA
}

\author{
Nofilia Faulina Perlambang \\ Program Studi Magister Manajemen Universitas Tarumanagara \\ nperlambang@yahoo.com \\ Eko Harry Susanto \\ Program Studi Magister Manajemen Universitas Tarumanagara
}

Masuk : 03-11-2020, revisi : 29-12-2020 diterima untuk diterbitkan : 29-12-2020

\begin{abstract}
The development of the paper industry has decreased as a result of widespread issues of climate change, global warming, deforestation, narrowing forest land and the transfer of paper use to digital. On the other hand, companies are required to continue producing in order to survive, develop and generate profits. One of the products made from paper raw materials that has experienced an increase in demand from year to year is tissue. In China, in order to boost the tourism sector, the government is campaigning for cleanliness, making the demand for tissue increasing. In Indonesia, one of the tissue products that supports the tourism sector by supplying tissue to hotels, restaurants and malls is Plenty. However, in the Indonesian paper industry, Plenty has to compete with other brands. One of its main competitors is Passeo which is owned by Sinarmas. This study aims to determine how far the relationship between green strategy, perceived quality and brand image affects purchase intention in Plenty's products in Jakarta. Data obtained from questionnaires distributed via googleform. The sample used in this study were 119 respondents. with the help of IBM SPSS Version 21, the result is green strategy, perceived quality and brand image have a positive effect on purchase intention.
\end{abstract}

Abstrak: Perkembangan industri kertas mengalami penurunan sebagai akibat dari merebaknya issue perubahan iklim, pemanasan global, penggundulan hutan, penyempitan lahan hutan dan pengalihan penggunaan kertas ke digital. Disisi lain perusahaan dituntut terus berproduksi untuk tetap bisa bertahan, berkembang dan menghasilkan keuntungan. Salah satu produk dari bahan baku kertas yang mengalami peningkatan permintaan dari tahun ketahun yaitu tissue. Di negara cina, guna menggenjot sektor pariwisata, pemerintah mengkampanyekkan kebersihan, membuat permintaan tissue semakin meningkat. Di Indonesia, salah satu produk tissue yang mendukung sektor pariwisata dengan cara menyuplai tissue ke hotel, restaurant dan mall yaitu Plenty. Namun di industry kertas Indonesia, Plenty harus bersaing dengan merek lain. Salah satu pesaing utamanya adalah Passeo yang dimiliki oleh Sinarmas. Penelitian ini bertujuan untuk mengetahui seberapa jauh hubungan strategi ramah lingkungan, persepsi kualias produk dan citra merek mempengaruhi minat beli pada produk Plenty di jakarta. Data diperoleh dari kuesioner yang disebar melalui googleform. Sampel yang digunakan dalam penelitian ini sebanyak 119 responden. dengan bantuan IBM SPSS Versi 21, teruji secara empiris strategi ramah lingkungan, persepsi kualias produk dan citra merek berpengaruh positif terhadap purchase intention.

Keywords: Green Strategy, Perceived Quality, Brand Image, Purchase Intention

\section{PENDAHULUAN}

Perkembangan industri kertas mengalami penurunan sebagai akibat dari merebaknya issue perubahan iklim, pemanasan global, penggundulan hutan, penyempitan lahan hutan dan pengalihan penggunaan kertas ke digital. Menurut data dari Global Forrest Watch hilangnya 
hutan primer Indonesia, mencapai lebih dari 6,02 juta ha dari 2000 sampai 2012 dan meningkat rata-rata sebesar 47.600 ha per tahun. (Hansen, 2013)

Namun disisi lain perusahaan dituntut terus berinovasi, beradaptasi dan berproduksi untuk tetap bisa bertahan, berkembang dan menghasilkan keuntungan di industri tersebut.

Seiring dengan perkembangan zaman, tissue merupakan benda yang tidak asing lagi di kehidupan sehari-hari, hampir setiap hari manusia menggunakan tissue. Tissue sendiri sekarang memiliki banyak varian mulai dari tissue basah, tissue gulung, tissue makan, dan sebagainya. Gaya hidup manusia yang ingin serba instan menyebabkan tissue menjadi hal yang sangat familiar belakangan ini. Berbeda pada saat tahun 70-an, dimana kain lap atau saputangan masih menjadi hal yang wajib dibawa saat berpergian.

Menurut data yang diperoleh dari Kementrian Perindustrian 2017, perkembangan industri tissue di Indonesia mengalami pertumbuhan dari tahun ke tahun Hal tersebut di sebabkan karena tissue merupakan produk yang dengan tingkat konsumsi tinggi dalam kehidupan rumah tangga. Kepraktisan dalam kebersihan yang ditawarkan ketika konsumen menggunakan tissue menjadi motif utama konsumen melakukan pembelian produk ini. Fenomena masyarakat kota besar memberikan peluang bagi para produsen pembuat tissue untuk memasarkan produknya bagi para konsumen.

Mengacu pada data diatas, menjadi alasan bagi peneliti untuk mengetahui faktor apa saja yang mempengaruhi minat beli produk Plenty. Judul dalam penelitian ini adalah "Pengaruh Green Strategy, Perceived Quality dan Brand Image terhadap Purchase Intention pada Produk Plenty di Jakarta".

\section{Tujuan Penelitian}

Tujuan dari penelitian ini untuk mengetahui pengaruh strategi ramah lingkungan, persepsi kualitas dan citra merek terhadap minat beli pada produk tissue Plenty diJakarta. Selain tiu untuk mengetahui faktor yang mempunyai pengaruh dominan terhadap minat beli tissue Plenty di Jakarta.

Berdasarkan uraian diatas maka hipotesis dalam penelitian ini dapat dirumuskan sebagai berikut:

H1: Green strategy berpengaruh positif terhadap purchase intention pada produk Plenty di Jakarta

H2: Perceived quality berpengaruh positif terhadap purchase intention pada produk Plenty di Jakarta

H3: Brand image berpengaruh positif terhadap purchase intention pada produk Plenty di Jakarta

\section{TINJAUAN PUSTAKA}

\section{Strategi ramah lingkungan}

Menurut (Chen, 2012), kegiatan pemasaran hijau adalah kegiatan yang melibatkan upaya perusahaan dalam mengembangkan, membedakan, berinovasi dan mempromosikan produk untuk memenuhi kebutuhan dan preferensi pelanggan tanpa menyebabkan kerusakan lingkungan.

\section{Persepsi kualitas}

Menurut (Wheelock \& Wilson, 1995), persepsi kualitas merupakan nilai relatif yang dimiliki produk dan harapan pelanggan terhadap produk. Ini berarti ketika pelanggan membeli produk tertentu, mereka membeli harapan dari produk.

\section{Citra produk}

Menurut (Magnusson \& Cranfield, 2003), citra produk merupakan persepsi konsumen tentang atribut merek tertentu (apakah merek itu inovatif, penuh gaya atau modis) dan merupakan komponen penting dari ekuitas merek. 


\section{Minat beli}

Minat beli merupakan keinginan yang muncul pada diri konsumen terhadap produk sebagai dampak dari proses pengamatan dan pembelajaran konsumen pada suatu produk.

\section{METODOLOGI PENELITIAN}

Populasi dalam penelitian ini adalah orang yang pernah mendengar produk Plenty di Wilayah Jakarta. Pemilihan sampel dilakukan dengan menggunakan metode non-probability sampling. Teknik non-probability sampling yang dipilih adalah teknik purposive.

Berdasarkan acuan dari (Hair \& Joseph, 2006) sebaiknya ukuran sampel diantara 30 sampai dengan 500 responden. Dengan acuan tersebut, peneliti memutuskan jumlah sampel yang digunakan pada penelitian ini sebesar 187 Responden. Untuk pengujian analisis validitas dan reliabilitas, analisis data dan asumsi analisis data digunakan perangkat lunak Statistical Package for the Social Sciences (SPSS) versi 21.

Penelitian menggunakan kuesioner yang dibagikan secara online, dengan menggunakan google form yang dibagikan pada tanggal 10 oktober - 20 oktober 2020. Pertanyaan filtering digunakan untuk menyaring data dari responden agar sesuai dengan penelitian. Yaitu, pernah mendengar produk tissue Plenty. Dan data yang dapat digunakan dalam penelitian ini 119 sampel, karena 68 responden tidak pernah mendengar produk tissue Plenty.

\section{Alat analisis yang digunakan}

Pengujain hipotesis dalam penelitain ini menggunakan regresi linier berganda. Regresi linear berganda ditujukan untuk menentukan hubungan linear antar beberapa variabel bebas yang biasa disebut $\mathrm{X}_{1}, \mathrm{X}_{2}, \mathrm{X}_{3}$, dan seterusnya dengan variabel terikat yang disebut $\mathrm{Y}$ (Situmorang, 2010).

\section{HASIL DAN KESIMPULAN}

Hasil penelitian ini menunjukkan bahwa pengujian validitas dan reliabilitas serta uji asumsi klasik model regresi sudah terbebas dari permasalahan normalitas, multikolinearitas dan heteroskedastisitas. Dengan demikian model regresi sudah tepat digunakan dalam pengujian hipotesis dalam penelitian ini.

Tabel 1

Uji t

Coefficients $^{\mathrm{a}}$

\begin{tabular}{|c|c|c|c|c|c|c|c|c|}
\hline \multirow{2}{*}{\multicolumn{2}{|c|}{ Model }} & \multicolumn{2}{|c|}{$\begin{array}{c}\text { Unstandardized } \\
\text { Coefficients }\end{array}$} & \multirow{2}{*}{$\begin{array}{c}\text { Standardized } \\
\text { Coefficients } \\
\text { Beta } \\
\end{array}$} & \multirow[t]{2}{*}{$\mathrm{t}$} & \multirow[t]{2}{*}{ Sig. } & \multicolumn{2}{|c|}{ Collinearity Statistics } \\
\hline & & $\mathrm{B}$ & Std. Error & & & & Tolerance & VIF \\
\hline \multirow{4}{*}{1} & (Constant) & 3.663 & 1.103 & & 3.320 & .001 & & \\
\hline & Green_Strategy & .154 & .051 & .220 & 3.007 & .003 & .650 & 1.539 \\
\hline & Perceived_Quality & .332 & .096 & .342 & 3.451 & .001 & .355 & 2.813 \\
\hline & Brand_Image & .223 & .075 & .319 & 2.961 & .004 & .300 & 3.335 \\
\hline
\end{tabular}

a. Dependent Variable: Purchase_Intention

Berdasarkan tabel tersebut dapat disusun persamaan regresi sebagai berikut:

$$
\mathrm{Y}=3,663+0.154 \mathrm{X} 1+0.332 \mathrm{X} 2+0.223 \mathrm{X} 3 \text {. }
$$

Adapun interpretasi dari persamaan regresi tersebut adalah:

1. $\alpha=0,465$ artinya minat beli konsumen sebesar 3,663 satuan jika strategi ramah lingkungan, persepsi kualitas dan citra merek bernilai nol.

2. $\beta 1=0,154$ artinya minat beli konsumen akan meningkat sebesar 0,154 satuan apabila strategi ramah lingkungan naik satu satuan dengan asumsi persepsi kualitas dan citra merek bernilai tetap.

3. $\beta 2=0.332$ artinya minat beli konsumen akan meningkat sebesar 0.332 satuan apabila persepsi kualitas naik satu satuan dengan asumsi strategi ramah lingkungan dan citra merek bernilai tetap 
4. $\beta 3=0.223$ artinya minat beli konsumen akan meningkat sebesar 0.223 satuan apabila citra merek naik satu satuan dengan asumsi kualitas produk dan persepsi kualitas bernilai tetap.

\section{Pengujian Hipotesis}

\section{Hipotesis Pertama}

Berdasarkan tabel 1 nilai sig sebesar $0,003: 2=0,0015(<0,05)$ yang artinya Ho1 ditolak, maka dapat disimpulkan bahwa terdapat pengaruh yang positif antara green strategy terhadap purchase intention pada produk Plenty di Jakarta.

\section{Hipotesis Kedua}

Berdasarkan tabel 1 nilai sig sebesar 0,001:2=0,0005 $(<0,05)$ yang artinya Ho2 ditolak, maka dapat disimpulkan bahwa terdapat pengaruh yang positif antara perceived quality terhadap purchase intention pada produk Plenty di Jakarta.

\section{Hipotesis Ketiga}

Berdasarkan tabel 1 nilai sig sebesar 0,004:2=0,002 $(<0,05)$ yang artinya Ho2 ditolak, maka dapat disimpulkan bahwa terdapat pengaruh yang positif antara perceived quality terhadap purchase intention pada produk Plenty di Jakarta.

\section{Tabel 2}

Uji F

ANOVA $^{\mathrm{a}}$

\begin{tabular}{|rl|r|r|r|r|r|}
\hline Model & & Sum of Squares & Df & Mean Square & F & \multicolumn{1}{c|}{ Sig. } \\
\hline \multirow{4}{*}{1} & Regression & 481.400 & 3 & 160.467 & 57.146 & $.000^{\mathrm{b}}$ \\
& Residual & 322.920 & 115 & 2.808 & & \\
& Total & 804.319 & 118 & & & \\
\hline
\end{tabular}

a. Dependent Variable: Purchase_Intention

b. Predictors: (Constant), Brand_Image, Green_Strategy, Perceived_Quality

Hasil yang diperoleh, nilai regresi Sig.nya 0.000 lebih kecil atau tidak lebih besar dari 0.05, sehingga Ho tidak ditolak dan dapat dikatakan bahwa green strategy, perceived quality dan brand image yang memiliki pengaruh positif terhadap purchase intention pada produk Plenty di Jakarta.

Untuk mengetahui seberapa besar pengaruh green strategy, perceived quality dan brand image terhadap purchase intention dapat dilihat melalui nilai Adjusted $\mathrm{R}^{2}$, hasil uji Adjusted $\mathrm{R}^{2}$ dapat dilihat dalam tabel sebagai berikut:

\section{Tabel 3}

\section{Uji Goodness of Fit}

Model Summary

\begin{tabular}{|l|r|r|r|r|r|}
\hline Model & $\mathrm{R}$ & R Square & $\begin{array}{c}\text { Adjusted R } \\
\text { Square }\end{array}$ & $\begin{array}{c}\text { Std. Error of the } \\
\text { Estimate }\end{array}$ & Durbin-Watson \\
\hline 1 & $.774^{\mathrm{a}}$ & .599 & .588 & 1.67571 & 2.108 \\
\hline
\end{tabular}

a. Predictors: (Constant), Brand_Image, Green_Strategy, Perceived_Quality

b. Dependent Variable: Purchase_Intention

Berdasarkan tabel 3 dapat diketahui hasil dari uji Adjusted $\mathrm{R}^{2}$ sebesar 0.588 yang artinya $58,8 \%$ variabel independen (green strategy, perceived quality, brand image) dapat menjelaskan variabel dependennya (purchase intention), sedangkan sisanya dipengaruhi oleh variabel lain di luar penelitian ini.

\section{Kesimpulan}

Tujuan penelitian ini adalah untuk menguji secara empiris green strategy, perceived quality dan brand image sebagai prediktor terhadap purchase intention. Berdasarkan hasil pembahasan yang didasarkan pada teori, penelitian yang relevan, kerangka pemikiran, hipotesis dan pengujian secara empiris yang berkaitan dengan semua hipotesis yang terdapat dalam penelitian ini, dapat dirumuskan kesimpulan sebagai berikut: 
1. Green strategy berpengaruh positif terhadap purchase intention. Jadi semakin sering perusahaan melakukan strategi pemasaran yang ramah lingkungan, maka semakin tinggi pula minat beli konsumen untuk membeli tissue plenty.

2. Perceived quality berpengaruh positif terhadap purchase intention. Jadi semakin bagus persepsi konsumen terhadap kualitas produk, maka semakin tinggi pula minat beli konsumen terhadap tissue plenty.

3. Brand image berpengaruh positif terhadap purchase intention. Jadi semakin baik citra merek Plenty, maka semakin tinggi pula minat konsumen untuk membeli tissue Plenty.

4. Kemampuan variabel green strategy, perceived quality dan brand image dalam menjelaskan purchase intentention sebesar 15,4\%, 33,2\% dan 22,3\%.

5. Variabel yang memiliki pengaruh terbesar yaitu perceived quality, kedua variabel brand image dan ketiga green strategy.

\section{DAFTAR PUSTAKA}

Chen, Y. S. (2012). The influences of green perceived quality and green brand awareness on green brand equity: The mediation effect of green perceived risk. Technology Management for Emerging Technologies, 45(1), 23-43.

Hair, \& Joseph, F. (2006). Multivariate Data Analysis. New Jersey: Prentice Hall, Inc.

Hansen. (2013). Global Forest Watch. infografik.

Magnusson, E., \& Cranfield, J. (2003). Canadian consumers' willingness to pay for pesticidefree food products: An ordered probit analysis. International Food and Agribusiness Management Review, 6(4), 13-30.

Situmorang. (2010). Data Penelitian; Menggunakan Program SPSS. Medan: USU Press.

Wheelock, D., \& Wilson, P. (1995). Explaining bank failures: Deposit Insurance, regulation, and efficiency. Journal of Money, Credit and Banking, 77(4), 689-700. 